\title{
Agronomic aspects of strip intercropping lettuce with alyssum for biological control of aphids
}

\author{
Eric B. Brennan* \\ United States Department of Agriculture/Agricultural Research Service, U.S. Agricultural Research Station, 1636 East Alisal Street, Salinas, CA 93905, USA
}

\section{H I G H L I G H T S}

- Agronomic aspects of intercropping lettuce with alyssum for aphid control.

- Lettuce was more competitive than alyssum and produced more shoot dry matter.

- Alyssum flower counts increased linearly with alyssum plant size. - Intercropping produced 2-15 open alyssum inflorescences per head of lettuce.

- Additive intercropping was more land-efficient than replacement intercropping.

\section{A R T I C L E I N F O}

\section{Article history:}

Received 25 September 2012

Accepted 27 March 2013

Available online 6 April 2013

\section{Keywords:}

Intercropping

Organic farming

Biological control of aphids

Lettuce

Alyssum

Vegetable production
G R A P H I C A L A B S T R A C T

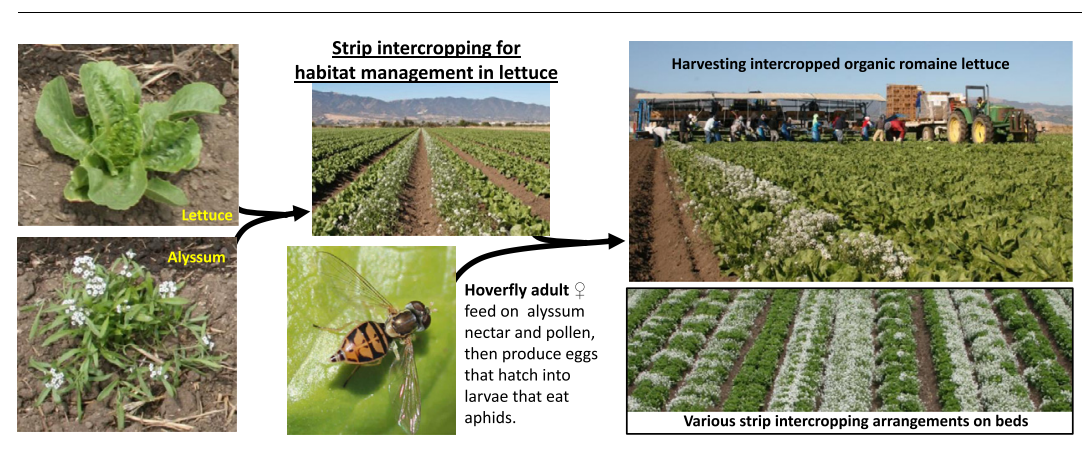

\begin{abstract}
A B S T R A C T
Organic lettuce growers in California typically use insectary strips of alyssum (Lobularia maritima (L.) Desv.) to attract hoverflies (Syrphidae) that provide biological control of aphids. A two year study with transplanted organic romaine lettuce in Salinas, California investigated agronomic aspects of lettuce monoculture and lettuce-alyssum strip intercropping on beds in replacement intercropping treatments where alyssum transplants replaced 2 to $8 \%$ of the lettuce transplants, and in additive intercropping treatments where alyssum transplants were added to the standard lettuce density without displacing lettuce transplants. Alyssum and lettuce dry matter (DM) were determined at lettuce maturity. Alyssum transplants produced less shoot DM in the additive than in the replacement intercropping treatments. The number of open inflorescences of alyssum increased with alyssum DM, and among treatments ranged from 2 to15 inflorescences per lettuce head. Compared with monoculture lettuce, lettuce heads on intercropped beds were slightly smaller and had lower nitrogen concentrations in the both additive treatments and in some replacement treatments. This research provides the first information on a novel additive intercropping approach to provide alyssum floral resources for biological control of lettuce aphids, and suggests that this approach may be a more land-efficient particularly for producing smaller lettuce heads for romaine hearts or for markets with less strict size requirements. Additional research is needed to determine if the increased competition between alyssum and lettuce in additive intercropping would reduce lettuce yields for wholesale markets with larger head size requirements. Practical aspects of implementing the various intercropping arrangements and alternatives are discussed.
\end{abstract}

Published by Elsevier Inc.

\footnotetext{
* Fax: +1 8317552814 .

E-mail address: Eric.Brennan@ars.usda.gov
} 


\section{Introduction}

Lettuce (Lactuca sativa L.) is the most economically important vegetable grown in Salinas valley on the central coast of California, with an annual production value of $\$ 1.2$ billion from 53,832 ha (Monterey County Agricultural Commissioner, 2011). Lettuce production here occurs year-round except during a mandatory lettuce-free period in December to break the disease cycle of aphidvectored lettuce mosaic virus (Wisler and Duffus, 2000). The currant-lettuce aphid (Nasonovia ribisnigri Mosley) is the primary insect pest of lettuce in the central coast (Smith et al., 2008) and is also a major lettuce pest worldwide (McCreight and Liu, 2012). This aphid is particularly difficult to control with contact insecticides because it colonizes the interior leaves (Liu, 2004). Conventional farms in California typically manage currant-lettuce aphid with systemic insecticides (Palumbo and Castle, 2009; Smith et al., 2008) and aphid-resistant cultivars (McCreight and Liu, 2012). In addition to higher-priced aphid-resistant cultivars, organic farms here rely heavily on biological control that is enhanced by intercropping lettuce with 'insectary plants' such as alyssum (Lobularia maritima (L.) Desv.) (Bugg et al., 2008; Gillespie et al., 2011; Smith et al., 2008). Intercropping describes systems where two or more crops are grown simultaneous in the same area of a field (Willey, 1979).

An insectary plant is 'a flowering plant which attracts and possibly maintains, with its nectar and pollen resources, a population of natural enemies which contribute to biological pest management on crops' (Parolin et al., 2012). Habitat management with insectary plants is a form of conservation biological control that can make highly disturbed agroecosystems for annual crops more favorable environments for natural enemies of agricultural pests (Jonsson et al., 2008; Landis et al., 2000). Fagan et al. (2010) highlighted the critical need for the lettuce industry to use biological control practices to develop sustainable long-term strategies for currant-lettuce aphid control, even in systems where aphid resistant varieties and conventional insecticides are available.

Alyssum is a perennial from the Mediterranean with an unusual ability to flower uninterrupted for extended periods (Pico and Retana, 2003), and in California it is a common ornamental that has naturalized in some coastal regions (DiTomaso and Healy, 2007). Alyssum is one of the most frequently studied species in habitat management for conservation biological control (Fiedler et al., 2008). Chaney (1998) identified alyssum as a promising insectary plant to intercrop with lettuce because alyssum flowered quickly after planting, was not overly aggressive or likely to become a weed, and attracted several beneficial species but few pest species. For more than 10 years, alyssum has been planted as an insectary plant in organic lettuce fields in California to attract adult hoverflies (Diptera: Syrphidae) that feed on pollen and nectar (Bugg et al., 2008).

Intercropping lettuce with alyssum increased the number of hoverfly larvae that are the most important natural enemies of aphids in lettuce in California (Chaney, 2003; Smith and Chaney, 2007; Smith et al., 2008). Several hoverfly species occur in California lettuce fields and larvae of the most voracious species can kill more than 160 currant-lettuce aphids daily (Hopper et al., 2011). Most adult hoverflies trapped in lettuce fields intercropped with alyssum contained large amounts of alyssum pollen in their gut (Gillespie et al., 2011). Hoverfly females require pollen for egg production (Schneider, 1948), and providing hoverflies with alyssum flowers increased their egg production and aphid suppression on lettuce (Hogg et al., 2011b). These studies explain why hoverfly larvae can significantly reduce aphid populations below economic thresholds in aphid-infested lettuce before harvest.

Lettuce-alyssum intercropping is clearly an effective biological control system for aphid control because it has been widely adopted by organic farmers and allows them to produce high quality lettuce without pesticides. While the interactions between alyssum and beneficial insect for biological control purposes have received considerable research attention in a variety of settings (Al-Doghairi and Cranshaw, 1999; Ambrosino et al., 2006; Begum et al., 2006, 2004; Berndt and Wratten, 2005; Goulson and Wright, 1998; Hogg et al., 2011a; Johanowicz and Mitchell, 2000; Karrou, 1998; Nafziger and Fadamiro, 2011; Pumarino and Alomar, 2012; Sivinski et al., 2006; Vattala et al., 2006), the agronomic interactions between alyssum and associated economic crops such as lettuce have been neglected. Vegetable growers in the major lettuce production regions need basic agronomic information on growth characteristics of intercropped alyssum and lettuce to maximize alyssum flower production per unit of land area to develop the most land-efficient intercropping arrangements that maximize the biological control aspects of alyssum, but also maintain high lettuce yields per unit of land. In the central coast region of California where most U.S. lettuce production occurs, this need for information is largely due to the high agricultural land rent costs (U.S. $\$ 3000-7000$ per ha) that restricts the amount of land area that growers can allocate to insectary plants that typically displace lettuce plants in the field. The minimum amount of alyssum flowers required for adequate aphid control in lettuce, and the optimal arrangement for lettuce-alyssum intercropping system is unknown. Lettuce-alyssum intercropping practices in California range from strip intercropping systems with alyssum on whole beds or rows at regular intervals such as every $48 \mathrm{~m}$ of lettuce beds (Gillespie et al., 2011), to scattered systems where alyssum plants are interspersed randomly through fields. However, in lettuce fields intercropped with alyssum, typically $5-10 \%$ of the arable area is used for in-field insectary strips (Bugg et al., 2008; Colfer, 2004). This $5-10 \%$ replacement of lettuce with alyssum plants is essentially the 'land opportunity cost' of biological control of aphids, which would be approximately $\$ 175-350$ per ha of lettuce assuming that 2 lettuce crops were produced per year in a field with an annual rental cost of $\$ 7000$ per ha; this estimate does not account for seed costs and labor to plant or manage weeds in the alyssum.

A two year study was conducted in transplanted organic romaine lettuce that was strip intercropped with several 'replacement' and 'additive' arrangements of alyssum from May to June. In the 'replacement' intercropping patterns, a standard transplant density was maintained and various amounts of lettuce transplants were replaced by alyssum transplants. In the 'additive' arrangements, the standard lettuce density was augmented with various amounts of alyssum transplants. The objectives were to (1) determine the relationship been alyssum shoot biomass and flower production, and (2) evaluate competition between the intercropped plants by measuring their shoot biomass and lettuce nitrogen uptake. I hypothesized that there would be more competition in the additive than replacement arrangements because of the greater total transplant density in the additive arrangements.

\section{Methods}

\subsection{Site description, field preparation, and soil amendments}

The experiments occurred at the USDA-ARS organic research farm in Salinas, CA (lat. 36.622658, long. -121.549172, elevation $37 \mathrm{~m}$ ), where the soil is a Chualar loamy sand (fine-loamy, mixed, superactive, thermic Typic Argixerol). The site has been certified organic since 1999, and inputs described were allowable under the USDA National Organic Program. The experiment occurred in a 48 by $15 \mathrm{~m}$ area on the east side of a 0.9 ha field that has been 
in a long-term commercial-scale trial (Brennan and Boyd, 2012) with an annual rotation of romaine lettuce (May-June), broccoli (July-October), and winter cover crops of legume cereal mixtures (October-March), since 2003. Romaine lettuce is here after referred to as lettuce. Cover crops were mowed and incorporated into the soil with a spader on 19 February 2008 and 13 March 2009. After a decomposition period, a tractor with lister plows was used to form peaked beds ( $101.6 \mathrm{~cm}$ wide) on 7 April 2008 and 17 April 2009. Urban yard waste compost $(\mathrm{C}: \mathrm{N} \approx 22)$ was broadcast at approximately $7.6 \mathrm{Mg}$ per ha (oven dry basis) onto the beds and incorporated with a rolling cultivator. Pelleted organic fertilizer of chicken manure and feather meal ( $8 \mathrm{~N}-1 \mathrm{P}-1 \mathrm{~K})$ was injected at 58 and $66 \mathrm{~kg} \mathrm{~N}$ per ha with a fertilizer applicator in two bands $27 \mathrm{~cm}$ apart, and approximately $15 \mathrm{~cm}$ deep in the peaked beds on 18 April 2008, and 24 April 2009, respectively. The peaked beds were then shaped with a bed harrow to produce a flat planting area on the bed top that was approximately $50 \mathrm{~cm}$ wide and $15 \mathrm{~cm}$ above the furrow bottoms.

\subsection{Experimental design and intercropping arrangement}

The experimental design was a randomized complete block with 4 blocks of eight treatments including lettuce monoculture (L100) and seven strip intercropping treatments. Each block was $10.2 \mathrm{~m}$ wide (10 beds) and $4.5 \mathrm{~m}$ (2008) or $10 \mathrm{~m}$ (2009) long. The experimental unit for each treatment was a single bed with two

\section{Bed dimensions and layout}

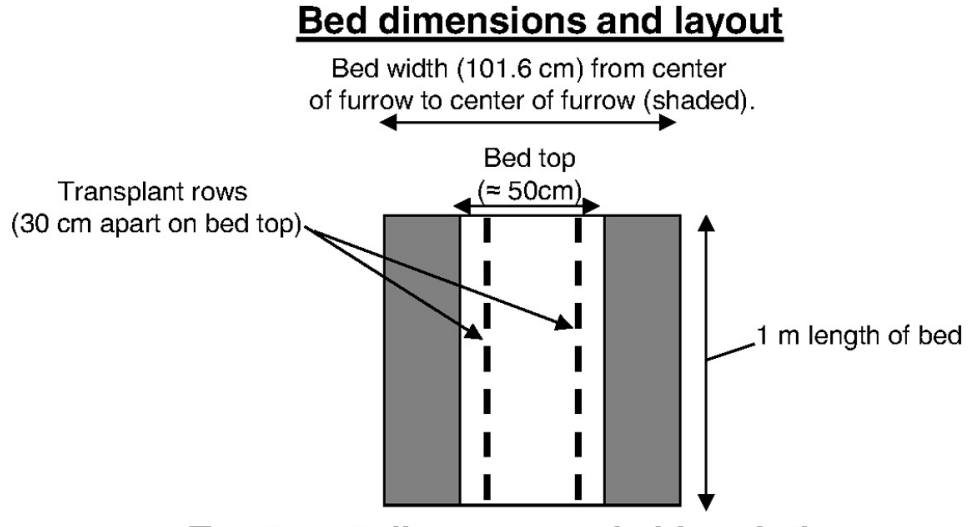

Treatment diagrams and abbreviations

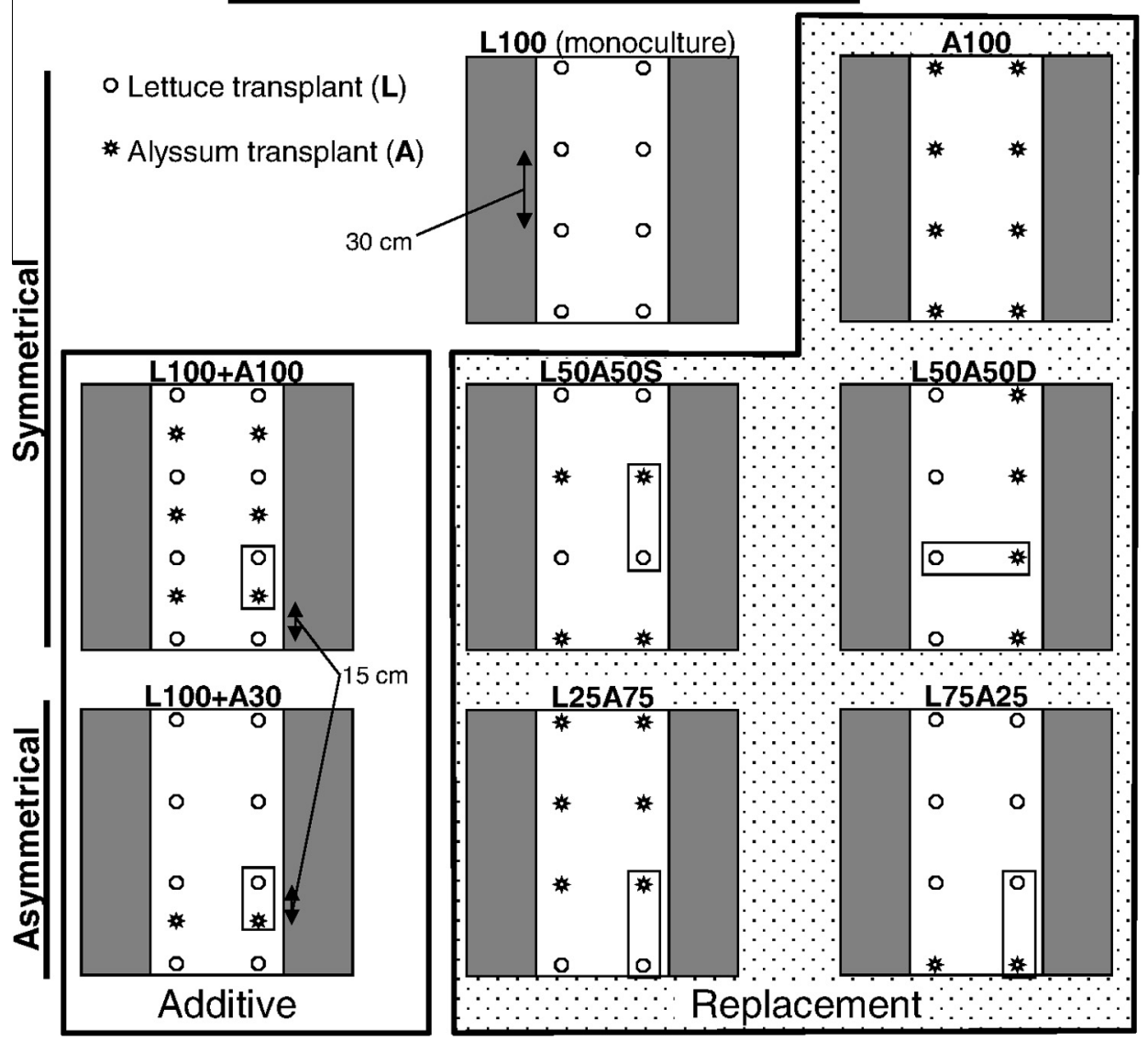

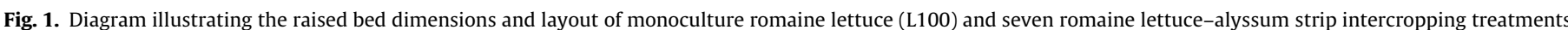

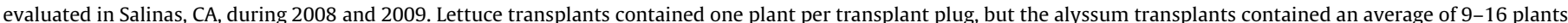

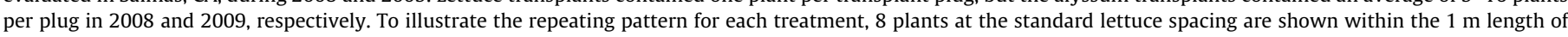

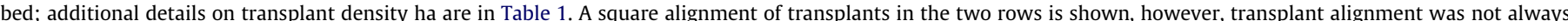

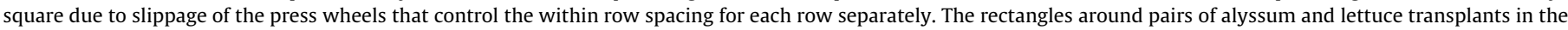
intercropped treatments indicate the adjacent pair of plants that were harvested for above ground dry matter measurement. 
plant rows. In addition to the eight treatments of interest, each block contained two additional lettuce-alyssum intercropping treatments that were not of interest and were excluded from the analysis. The furrow between adjacent beds was considered an adequate buffer area to prevent below or above ground competition between adjacent treatments because the furrow was cultivated $15-18 \mathrm{~d}$ after transplanting (DAT) and remained dry throughout the remainder of the crop, and because the canopies of the plants on adjacent beds did not overlap during the study.

Intercropping was evaluated in various patterns on two rows per bed to simulate strip intercropping as practiced in commercial organic lettuce fields in the region. The intercropping treatments included five 'replacement' treatments (A100, L25A75, L50A50D, L50A50S, L75A25) with the same total transplant density (65333 transplants per ha) as L100, and two 'additive' treatments $(\mathrm{L} 100+\mathrm{A} 100, \mathrm{~L} 100+\mathrm{A} 30)$ with the lettuce density of L100 plus additional alyssum transplants at 5333 or 1600 transplants per ha, respectively (Fig. 1, Table 1). The replacement treatment abbreviations refer to the percentage of lettuce (L) and alyssum (A) on the intercropped beds. The percentage of lettuce plants displaced by alyssum per ha in the replacement treatments ranged from $2 \%$ in L75A25 to 8\% in A100 (Table 1). In this scenario, I assumed each intercropping treatment would occupy 8 evenly spaced beds in a 1 ha field containing 98 beds. For example, all 98 beds would be in lettuce in L100, whereas A100 would have 90 beds of lettuce and eight beds of $100 \%$ alyssum (i.e. one alyssum bed followed by 11 lettuce beds with the first alyssum bed at bed seven). The ' $D$ ' and ' $S$ ' of the L50A50 treatments indicate if the 50\% lettuce and $50 \%$ alyssum ratio occurred on the same row (S) or different row (D) of the bed. Alyssum did not replace lettuce in the additive treatments, but instead was inserted between lettuce plants within the row. Therefore, the additive treatment abbreviations $(\mathrm{L} 100+\mathrm{A} 100, \mathrm{~L} 100+\mathrm{A} 30)$ refer to the $\mathrm{L} 100$ plus $(+)$ the percentage of alyssum in A100.

\subsection{Transplanting procedures}

Transplants of 'Sunbelt' romaine lettuce (Central Valley Seeds Inc., Salinas, CA, USA) and alyssum ('Sweet Alyssum', Kamprath Seed Inc. Manteca, CA, USA) were produced in a commercial greenhouse in 2.5 square by $5 \mathrm{~cm}$ deep cells in plastic trays for transplanting 35-40 d later. Lettuce transplants contained one plant per cell, whereas alyssum transplants had an average of nine and
16 plants per cell in 2008 and 2009, respectively. In this paper, 'transplant' refers to a single lettuce plant grown in one cell or a group of 9-16 alyssum plants grown in one cell. Alyssum transplants grown for beneficial insect habitat in this region typically contain multiple plants per transplant plug because seed singulation is not possible with small raw seed that is used for the automated system for seeding transplant trays; furthermore, raw alyssum seed is inexpensive (approximately U.S. \$ 30-55 per $\mathrm{kg}$ ) and transplant plugs with multiple plants are easier to pull from the transplant tray (with less plant damage) and load by hand in a mechanical transplanter. A hand loaded cell-type carrousel transplanter was used to transplant the lettuce in two rows (Fig. 1) at a density of 65,333 transplants per ha on May 4 and 5 in 2009 and 2008 , respectively. After transplanting the lettuce on all beds, the seven intercropping treatments with alyssum at various densities and arrangements (Fig. 1) were created by hand with a trowel as needed by replacing lettuce transplants with alyssum in the replacement treatments, or adding alyssum between lettuce in the additive treatments.

\subsection{Post-transplanting management and climate}

Sprinkle irrigation was applied immediately after transplanting and during the subsequent 15-18 DAT, after which drip irrigation with a single drip tape line at the bed center was used. Irrigation scheduling was based on daily evapotranspiration from the (California Irrigation Management Information System), and soil moisture sensors. No precipitation occurred during the trial and total irrigation was $150 \mathrm{~mm}$ (2008) and $133 \mathrm{~cm}$ (2009). The climatic conditions were similar across years with average air of $14{ }^{\circ} \mathrm{C}$ and soil temperature of $22^{\circ} \mathrm{C}$, however evapotranspiration was higher during 2008. Liquid, fish-based fertilizers (6N-2P-0K, $5 \mathrm{~N}-$ $1 \mathrm{P}-1 \mathrm{~K}$ ) were applied through the drip tape at 25 to 35 DAT to bring the total rate of $\mathrm{N}$ applied (preplant + fertigation) to 69 and $73 \mathrm{~kg} \mathrm{~N}$ per ha, in 2008 and 2009, respectively. Weeds were controlled with a tractor mounted cultivator and hand-hoeing on 19 and 15 DAT in 2008 and 2009, respectively.

\subsection{Plant sampling and tissue analysis}

Shoot dry matter (DM) was determined for lettuce and alyssum at $42 \mathrm{~d}$ after transplanting, on 15 and 16 June in 2009 and 2008, respectively; these harvest dates were 7 and $4 \mathrm{~d}$ prior to when

Table 1

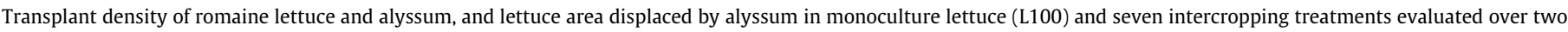
years in Salinas, CA.

\begin{tabular}{|c|c|c|c|c|c|c|c|c|c|}
\hline \multirow[t]{2}{*}{ Treatment $^{\mathrm{d}}$} & \multicolumn{2}{|c|}{ Adjacent to same species within row ${ }^{\mathrm{a}}$} & \multicolumn{3}{|c|}{ Adjcent to other species within row ${ }^{b}$} & \multicolumn{3}{|c|}{ Transplant density ${ }^{\mathrm{c}}$} & \multirow[t]{2}{*}{ Lettuce displaced $(\%)^{\mathrm{f}}$} \\
\hline & $\begin{array}{l}\text { Lettuce } \\
\text { (Transplants per } 3 \mathrm{~m} \mathrm{c}\end{array}$ & $\begin{array}{l}\text { Alyssum } \\
\text { of bed })^{\mathrm{e}}\end{array}$ & Lettuce & Alyssum & Total & $\begin{array}{l}\text { Lettuce } \\
\text { (Transpl }\end{array}$ & $\begin{array}{l}\text { Alyssum } \\
\text { s per ha) }\end{array}$ & Total & \\
\hline A100 & 0 & 20 & 0 & 0 & 20 & 60,000 & 5333 & 65,333 & 8 \\
\hline L25A75 & 0 & 6 & 4 & 10 & 20 & 61,067 & 4267 & 65,333 & 6 \\
\hline L50A50D & 10 & 10 & 0 & 0 & 20 & 62,667 & 2667 & 65,333 & 4 \\
\hline L50A100S & 0 & 0 & 10 & 10 & 20 & 62,667 & 2667 & 65,333 & 4 \\
\hline L75A25 & 6 & 0 & 10 & 4 & 20 & 64,267 & 1067 & 65,333 & 2 \\
\hline L100 & 20 & 0 & 0 & 0 & 20 & 65,333 & 0 & 65,333 & - \\
\hline $\mathrm{L} 100+\mathrm{A} 30$ & 6 & 0 & 14 & 6 & 26 & 65,333 & 1600 & 66,933 & 0 \\
\hline $\mathrm{L} 100+\mathrm{A} 100$ & 0 & 0 & 20 & 20 & 40 & 65,333 & 5333 & 70,666 & 0 \\
\hline
\end{tabular}

a Number of lettuce transplants adjacent only to lettuce, and number of alyssum transplants adjacent only to alyssum within a row.

b Number of lettuce transplants adjacent to alyssum, and number of alyssum transplants adjacent to lettuce within a row.

c Density assuming that the treatments were applied to eight beds in a 1-ha field containing $98,100 \mathrm{~m}$ long beds ( $9800 \mathrm{~m}$ of total bed length) that were $101.6 \mathrm{~cm}$ wide.

d Treatment codes indicate the percentage of lettuce (L) and alyssum (A) in monocropped lettuce (L100), replacement intercropping treatments (A100, L25A75, L50A50D,

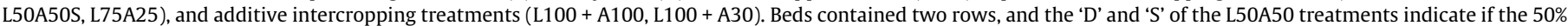

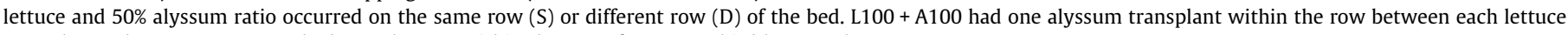
transplant, whereas, $\mathrm{L} 100+\mathrm{A} 30$ had one alyssum within the row after every third lettuce plant.

e The number of transplants in two rows of a $3 \mathrm{~m}$ section of a bed.

${ }^{f}$ Percentage of lettuce plants per ha that were displaced by alyssum transplants in the intercropping treatment compared with the L100 treatment. 
the lettuce in the remainder of the field was harvested by a commercial crew in 2008 and 2009, respectively. Lettuce shoots are hereafter referred to as 'heads'. For L100 and A100, the DM harvests included one transplant from one randomly chosen row in each bed in 2008 , and one transplant from both rows in each bed in 2009. A similar procedure was used to determine lettuce and alyssum DM in the treatments with both plant types by harvesting one adjacent alyssum-lettuce transplant pair from one randomly chosen row in each bed in 2008, and one adjacent alyssum-lettuce transplant pair from both rows in each bed in 2009 (Fig. 1). Harvests occurred at least $1 \mathrm{~m}$ from the end of each bed. Harvested plant tissue was oven-dried at $65{ }^{\circ} \mathrm{C}$ for at least $48 \mathrm{~h}$ until the weights had stabilized. Prior to oven-drying the alyssum shoots in 2008 , the number of open inflorescences per transplant were counted to determine the relationship between alyssum transplant DM and the number of open inflorescences using regression analysis; open inflorescences were inflorescences with at least 1 open flower. The regression analysis of open inflorescences in 2008 was based on 1 randomly chosen alyssum plant from all four blocks harvested on 16 June and an additional randomly chosen plant from three blocks on 17 June. The equation derived from the regression analysis was used to estimate the number of open inflorescences per ha and the number of open inflorescences per head of lettuce assuming the strip intercropping patterns for a 1 ha field described in 2.3 and table 1 . To estimate the number of open alyssum inflorescences per unit area and open inflorescences per lettuce head in the asymmetrical treatment, L25A75, the DM of the alyssum transplants in A100 was used for alyssum transplants adjacent only to alyssum within the row. This procedure was used for the of the asymmetrical treatments because a separate experiment had determined that there was no significant difference between DM of alyssum transplants in A100 and alyssum transplants adjacent only to alyssum within a row in L25A75 (Brennan, unpublished data).

Harvested lettuce heads from 2009 was analyzed with the combustion gas analyzer method for total nitrogen (N) at the Agriculture and Natural Resources Analytical Laboratory at the University of California (Davis).

\subsection{Statistical analysis}

All analyses were conducted with SAS version 9.3 (SAS Inst. Cary, NC) using the MIXED procedure. In the analyses, treatment, year and their interaction were considered as fixed effects and block nested within year was a random effect. Data were checked to meet the assumptions of ANOVA and were transformed where necessary although back transformed data are presented. Log transformation was used for alyssum open inflorescences per ha, and alyssum open inflorescences per head of lettuce. A preplanned contrast was used to compare the number of open alyssum inflorescences per $g$ of alyssum DM in the additive versus replacement intercropping treatments for 2008. Dunnett's test which controls the family wise error rate for multiple comparisons (Westfall et al., 1999) was used to compare the DM of romaine heads in the L100 treatment to the other treatments $(P \leqslant 0.06)$ and lettuce $\mathrm{N}$ concentration $(P \leqslant 0.01)$, and similarly to compare DM of alyssum in A100 to the other treatments $(P \leqslant 0.001)$. Preplanned contrasts were used to compare the replacement versus additive treatments for the lettuce DM, lettuce $\mathrm{N}$ concentration, and alyssum DM. The MEANS procedure was used to calculate $95 \%$ confidence intervals $(\mathrm{CI})$ of the response variables to help readers make practical inferences about the data. Comparisons between treatment means with $95 \% \mathrm{CI}$ can be made using the 'rule of eye' method whereby intervals that overlap with a mean are not different, and intervals that overlap by half of one interval arm are significantly different at $P \approx 0.05$ (Cumming, 2009); however, such comparisons are not adjusted to control the family wise error rate for multiple comparisons and are more robust when samples sizes are at least 10 . The REG procedure was used to obtain the regression equation between open inflorescences and alyssum DM.

\section{Results and discussion}

\subsection{Alyssum shoot dry matter production}

Shoot DM of individual alyssum transplants differed between intercropping treatments $\left(F_{6,35.3}=9.98, \quad P<0.001\right)$ and years $\left(F_{1,6.08}=7.29, P=0.035\right)$, and the lack of a significant treatment $x$ year interaction $\left(F_{6,35.3}=1.09, P=0.386\right)$ indicated that treatments performed consistently across years (Fig. 2A). Averaged across treatments, alyssum transplants produced less DM in 2008 (25 g per transplant) than 2009 (30 g per transplant), possibly because the higher $\mathrm{ET}_{\mathrm{o}}$ in 2008 increased plant stress.

Alyssum shoots averaged $31 \mathrm{~g}$ per transplant in the replacement treatments and were $12 \mathrm{~g}$ larger than the average $19 \mathrm{~g}$ per transplant in the additive treatments $\left(F_{1,35.5}=57.2, P<0.001\right)$ (Fig. 2A). Compared with A100, alyssum shoot DM was lower in the additive treatments but not in the replacement treatments (Dunnett's test, $P \leqslant 0.001$ ). Based on the overlapping confidence intervals, alyssum shoot DM did not appear to differ between the additive treatments $(\mathrm{L} 100+\mathrm{A} 100, \mathrm{~L} 100+\mathrm{A} 30)$ indicating that alyssum growth was affected by lettuce density but not total transplant density that was higher in $\mathrm{L} 100+\mathrm{A} 100$ (26 transplants per $3 \mathrm{~m}$ of bed) versus $\mathrm{L} 100+\mathrm{A} 30$ (40 transplants per $3 \mathrm{~m}$ of bed) (Table 1). Although not quantified, the canopies of alyssum and lettuce within a bed began to overlap at approximately $22 \mathrm{~d}$ after transplanting in the additive treatments compared with $10 \mathrm{~d}$ later in the replacement treatments; this is illustrated with the replacement treatment L50A50S and the additive treatment L100 + A100 (Fig. 3). This figure and the lower alyssum DM in the additive than replacement treatments (Fig. 2A) suggest that competition between alyssum and lettuce in the additive treatments began earlier in the season and was more intense than occurred in the replacement intercropping treatments.

\subsection{Lettuce head dry matter production}

Lettuce head DM differed among treatments $\left(F_{6,34.9}=8.70\right.$, $P<0.001)$, however, year $\left(F_{1,5.79}=3.5, P=0.11\right)$, and year $\mathrm{x}$ treatment $\left(F_{6,34.9}=0.58, P=0.74\right)$ were not significant. Lettuce individual head DM ranged from 38 to $51 \mathrm{~g}$, and was higher on average in the replacement ( $45 \mathrm{~g}$ per transplant) than additive treatments (38 g per transplant) $\left(F_{1,35}=20.2, P<0.001\right)$ (Fig. $\left.2 \mathrm{~B}\right)$. The narrower $\mathrm{CI}$ indicated that lettuce head weight was most uniform in L100 and $\mathrm{L} 100+\mathrm{A} 100$, possibly because competition was least variable in these treatments. There was an unexpected transplant arrangement effect on lettuce head weight between L50A50D (42 g per transplant) and L50A50S (51 g per transplant) that both had 10 lettuce and 10 alyssum transplants per $3 \mathrm{~m}$ of intercropped bed (Fig. 2B, Table 1). The lower head weight in L50A50D than L50A50S indicated that lettuce experienced less competition in L50A50S where it was evenly distributed between both rows of the bed, and where it had immediate alyssum neighbors within the row. Furthermore, L50A50S was the only intercropped treatment with lettuce and alyssum on the same bed that had the same lettuce head weight as L100 (Dunnett's test, $P \leqslant 0.06$ ) (Fig. 2B).

On a per-transplant basis, lettuce was more competitive than alyssum because lettuce DM was only $25 \%$ less in the highest density intercropping treatment (L100 + A100) than in L100, whereas alyssum DM was 46\% less in L100 + A100 than in A100 (Fig. 2A and $\mathrm{B}$ ). Averaged across years, alyssum transplants grown alone on beds (A100) contained 32\% less DM than lettuce transplants 

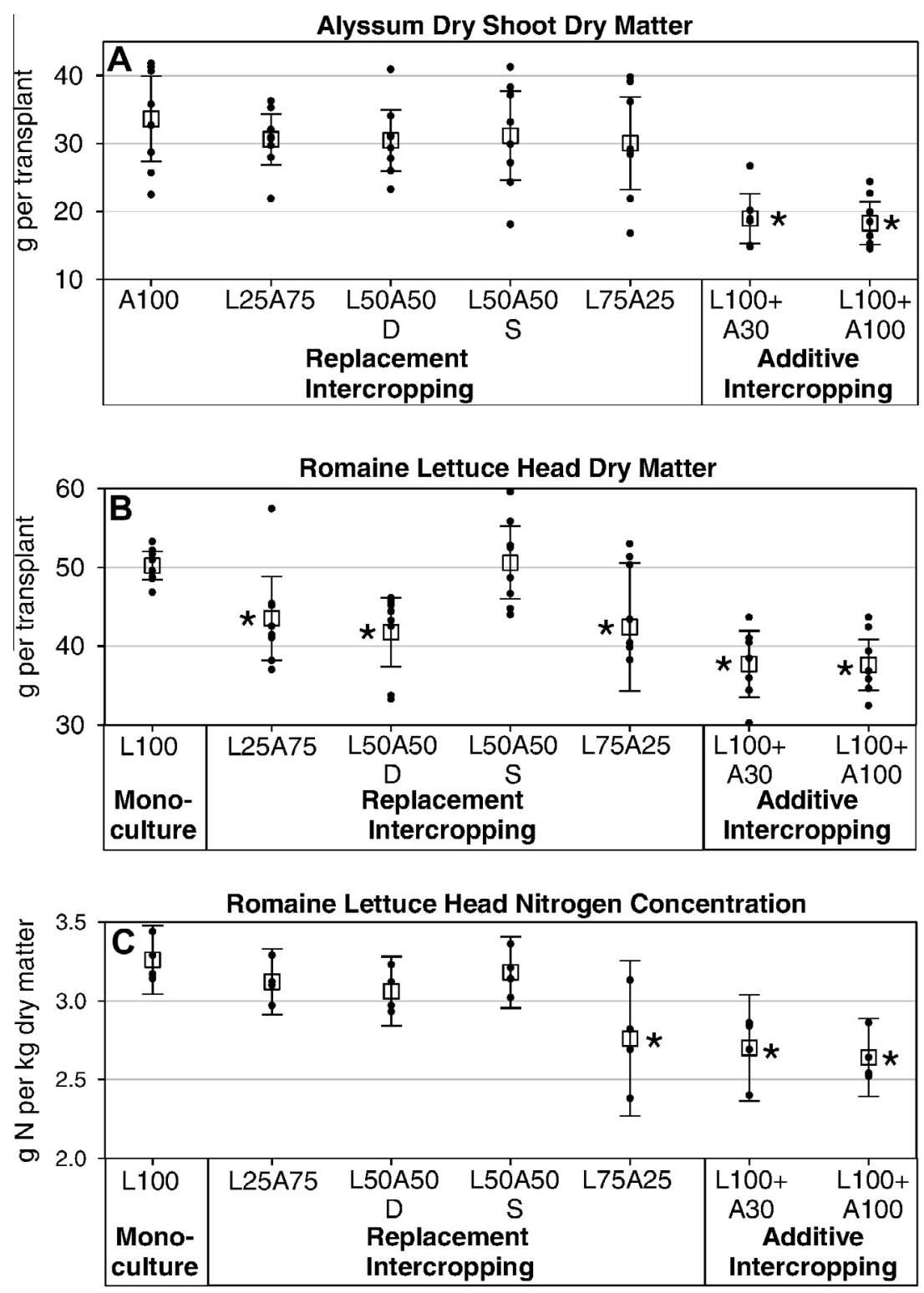

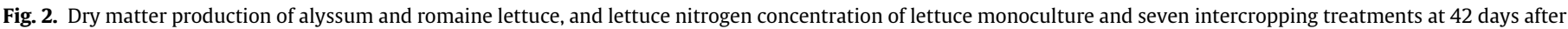

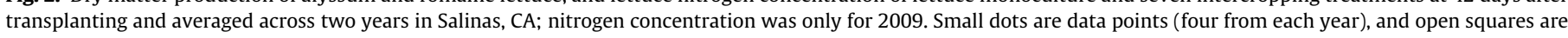

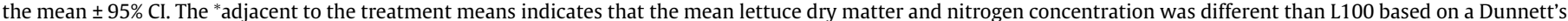

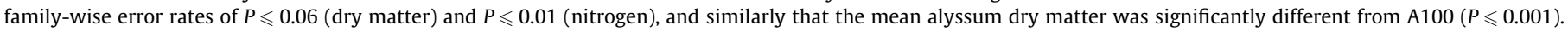

grown alone on beds (L100) (Fig. 3B). This demonstrates that lettuce was more productive than alyssum in terms of shoot DM at the standard planting density for lettuce. Previous studies found that shoot biomass is a good predictor of competitive ability (Gaudet and Keddy, 1988; Keddy et al., 2002).

\subsection{Lettuce head nitrogen concentration in 2009}

The $\mathrm{N}$ concentration of lettuce heads ranged from 2.6 to $3.3 \mathrm{~g}$ per $\mathrm{kg}$ and differed among treatments $\left(F_{6,21}=7.53, P<0.001\right)$, and compared to L100, N concentrations were lower in L75A25 and both additive treatments (Dunnett's test, $P \leqslant 0.01$ ) (Fig. $2 \mathrm{C}$ ). At the same lettuce density, lettuce $\mathrm{N}$ concentration was approximately $20 \%$ greater in L100 than in the additive treatments, suggesting that lettuce and alyssum competed for $\mathrm{N}$ in the additive treatments. The cause of the greater variability in $\mathrm{N}$ concentration in L75A25 than the other replacement treatments may have been because the sampled lettuce in this treatment experienced compe- tition within the row from lettuce on one side and alyssum on the other side; in contrast, the lettuce in the other replacement treatments were between lettuce alone (L50A50D) or alyssum alone (L25A75, L50A50S) within the row. Lettuce head $\mathrm{N}$ content in L100 was $108 \mathrm{~kg}$ per ha which was similar to the $107 \mathrm{~kg}$ per ha previously reported for romaine lettuce in this region (Breschini and Hartz, 2002).

\subsection{Relationship between alyssum shoot dry weight and flowering}

There was a significant, positive, linear relationship between alyssum shoot DM and the number of open inflorescences per transplant (Fig. 4). The number of open inflorescences per alyssum transplant did not differ significantly among intercropped treatments $\left(F_{6,39}=1.67, P=0.155\right)$, however, the mean number tended to be highest in $A 100$ (168), intermediate in the other replacement treatments (140-153), and lowest in the additive treatments (116-121) (Fig. 5A). The additive intercropping treatments 

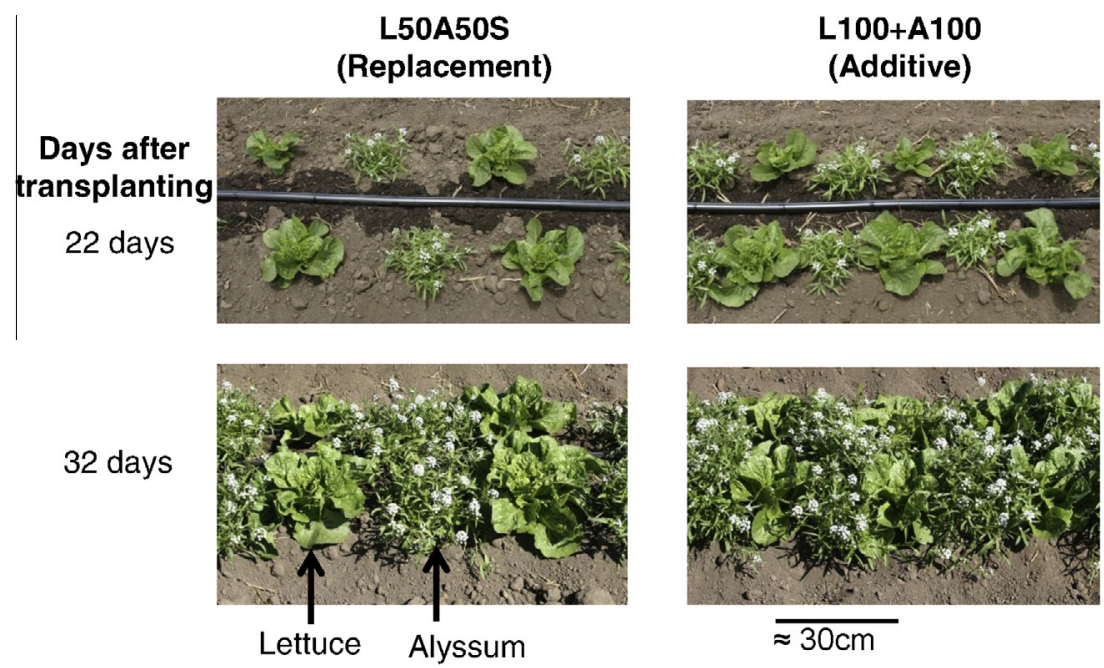

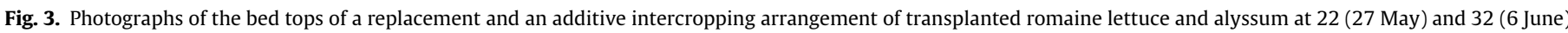

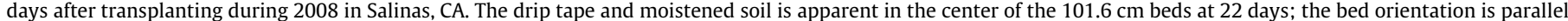

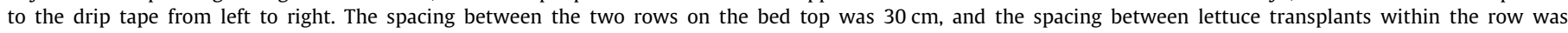

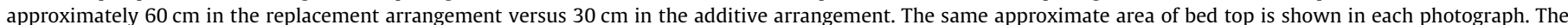

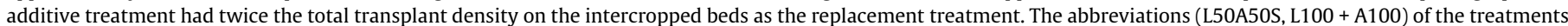
shown are described further in Fig. 1 and table 1.

$(\mathrm{L} 100+\mathrm{A} 100, \mathrm{~L} 100+\mathrm{A} 30)$ had significantly more open inflorescences per $g$ of alyssum DM $(6.6 \pm 0.8$, mean $\pm 95 \% \mathrm{CI})$ than the replacement intercropping treatments $(5.2 \pm 0.26)\left(F_{1,35.9}=24.85\right.$, $P<0.001)$; this indicates that alyssum transplants allocated more DM to flower production in the additive treatments where competition was more intense than in the replacement treatments.

Assuming that the intercropping treatments occurred on 8 beds in a 1 ha field with $9800 \mathrm{~m}$ of bed length, the estimated number of open alyssum inflorescences per head of lettuce or per $\mathrm{m}^{2}$ of field area differed significantly between treatments $\left(F_{6,38.1}=169.6\right.$, $P<0.001$ ) ranging from 2 to 15 per head of lettuce, or 1492 per $\mathrm{m}^{2}$ of field area (Fig. 5B). This figure also illustrates the clear positive trend between alyssum transplant density per ha and the number of open inflorescences per head of lettuce or per $\mathrm{m}^{2}$ of field area. Averaged across treatments, the estimated number of open inflorescences per head of lettuce was slightly lower $\left(F_{1,38.1}=10.1, P=0.003\right)$ in $2008(6.1 \pm 0.5$, mean $\pm 95 \% \mathrm{CI})$ than

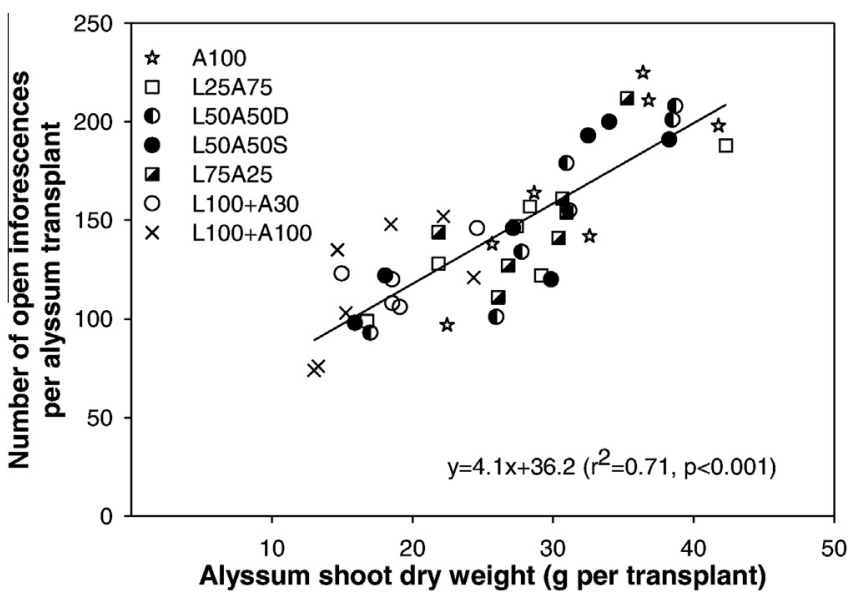

Fig. 4. Relationship between alyssum shoot dry matter and number of open inflorescences in seven intercropping treatments of organic romaine lettuce and alyssum in Salinas, CA in 2008. Plants were harvested from 42 and 43 days after transplanting. Data points represent individual transplants whereby one or two plants were harvested from each of the four blocks.
$2009(6.9 \pm 0.6)$, and year $\mathrm{x}$ treatment was not significant $\left(F_{6,38.1}=1.0, P=0.44\right)$.

\subsection{Management implications and practical application}

Several issues should be considered when determining which of the intercropped treatments or modification of them would be most practical to implement on a commercial scale to (1) achieve successful biological control of aphids in transplanted lettuce, (2) maximize lettuce yield and profitability, and (3) minimize the costs and complications with transplanting, weed management, harvest, marketing, and post-harvest tillage. The data presented here suggest more uniformity in lettuce head size in intercropped treatments with symmetrical competition within the row (L50A50D, L100 + A100). Head uniformity is more critical with large size lettuce than with smaller size lettuce for romaine hearts or direct sale of individual heads to consumers at farmers markets.

The yield of a romaine lettuce field that is harvested for full size heads depends on the number of lettuce plants per ha that are marketable based on a minimum head size, and other quality characteristics (i.e. disease symptoms, physiological defects, and insect damage). Assuming that head size was the only criteria limiting marketable yield, monoculture lettuce (L100) at a density of 65,333 lettuce plants per ha has a potential maximum yield of 2722 boxes per ha of full size heads ( 24 heads per box). Based on the lettuce plant densities of the various intercropped treatments in this study (Table 1), the yield potential in 24 count boxes per ha in the replacement treatments would theoretically range from 2500 boxes (in A100 where alyssum displaced $8 \%$ of the lettuce) to 2677 boxes (in L75A25 where alyssum displaced $2 \%$ of the lettuce), and 2722 boxes in the additive treatments where alyssum was added to the standard density of L100. Although this suggests that there would be a yield advantage in the additive versus replacement treatments, additional research is needed to determine if the lettuce plants in the additive treatments that produced approximately $25 \%$ less shoot DM than $\mathrm{L} 100$, are able to produce large enough heads for marketable size standards. The reduction in lettuce shoot dry DM that was apparent in the additive treatments and all replacement treatments except L50A50s, may have a relatively minimal effect on the weight of a box of lettuce or 

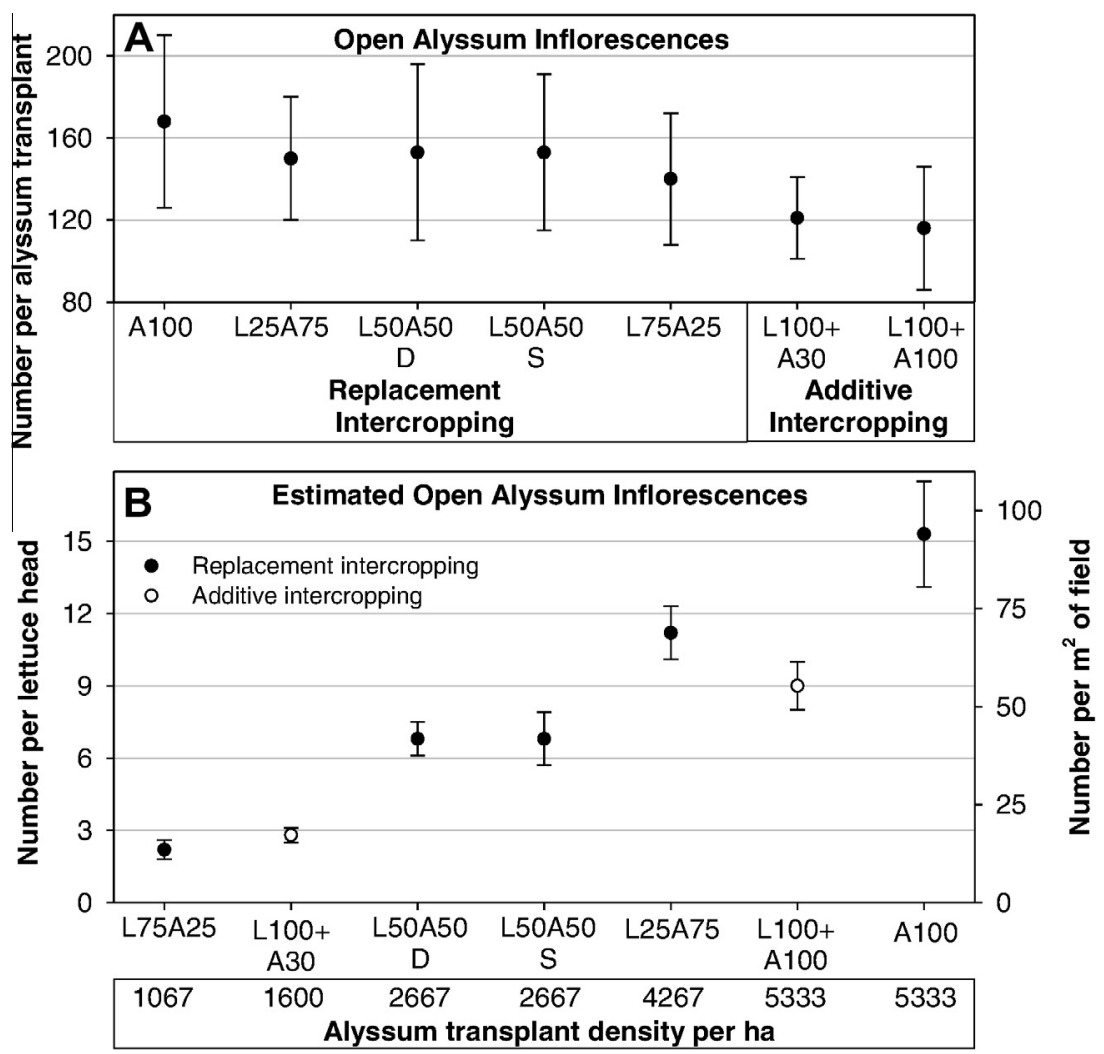

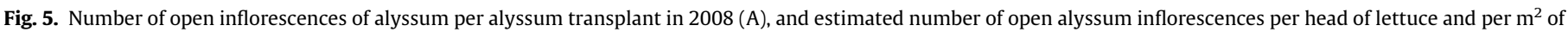

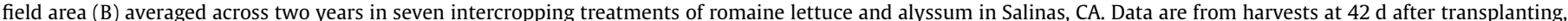

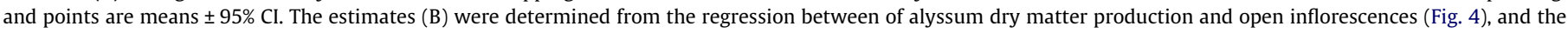

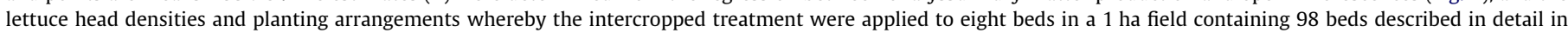

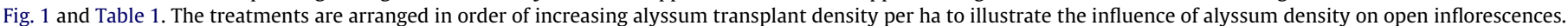

the total yield of a field after the harvest crew trims down the heads and packs them in boxes. The gross weight of a 24 count box of organic romaine lettuce for wholesale in this region can range from approximately $11-14 \mathrm{~kg}$ per box, however, a minimum of $13.6 \mathrm{~kg}$ per box may be necessary for wholesale during a typical year when the lettuce supply is high (Brennan, unpublished data). To achieve a $13.6 \mathrm{~kg}$ box weight for 24 heads, the average trimmed fresh head weight would need to be approximately $515 \mathrm{~g}$ which corresponds to approximately $31 \mathrm{~g}$ of DM; this assumes that the empty box weight is $1.24 \mathrm{~kg}$ and a typical moisture content of $94 \%$. The average DM of the untrimmed heads in this study ranged from 38 to $51 \mathrm{~g}$ (Fig. 1). It is important to point out that during commercial lettuce harvests, individual heads are not weighed, however, quality control inspectors routinely check the weight of a random sample of packed boxes. Furthermore, the box weight requirements are somewhat flexible, particularly with organic lettuce, depending on the lettuce supply and demand at various times of the year.

Hand-loaded cell-type carrousel transplant implements used in this region have several carrousels, each that is loaded by one person and which plants a single row. Therefore, intercropping treatments A100 and L50A50D would be the easiest to plant because plant type is constant within a row, whereas the other treatments with alternating arrangements within a row would not be practical on a commercial scale, especially those that alternated every other plant (i.e. L50A50S and L100 + A100). However, an alternative to the strip intercropping treatments evaluated here would be to intersperse alyssum in all rows of lettuce throughout the field. For example, to achieve a density of approximately seven alyssum open inflorescences per head of lettuce, as in L50A50S and L50A50D where 4 percent of the field was alyssum transplants, the 2667 alyssum transplants per ha could be distributed across all 196 rows (two rows per bed, and 98 beds per ha) where one alyssum transplant would occur approximately every $7.3 \mathrm{~m}$ or after every 24 lettuce plants in each row. To implement this, four alyssum transplants could be interspersed in a transplant tray with 100 cells of lettuce. This approach is currently being used by some growers in the region as an alternative to strip intercropping. This alternative approach may have several potential advantages. First, it could minimize competition between lettuce and alyssum by spreading alyssum though the whole field thus reducing the number of small heads. Any small heads would be more evenly distributed through the field so that they could be conveniently mixed in boxes with larger lettuce heads to ensure the box still meets the minimum box weight. Second, it would distribute the alyssum pollen and nectar for adult hoverflies more evenly throughout the field rather than in concentrated strips. This may facilitate adult hoverfly movement throughout the field; however, studies have not evaluated if there are differences in biological control of aphids in lettuce fields with concentrated strip versus scattered plantings of alyssum. Third, it would improve weed management by eliminating concentrated strips of alyssum that are difficult to hand weed; concentrated strips of alyssum are difficult to hand weed because it is difficult to see the weeds between adjacent alyssum plants within a row. Weed management is expensive in organic systems in this region and weeds that escape hand weeding can produce seed that infest future crops and increase weeding costs. In a long term rotational study with organic vegetables, weed densities were often higher on beds that have been used repeatedly for concentrated strips of alyssum such as A100 (Brennan, unpublished data). Fourth, scattering alyssum insectary plants throughout a field may minimize post-harvest tillage requirements because alyssum residue would be more evenly distributed 
throughout the field rather than in concentrated strips; alyssum shoot residue is less succulent than lettuce residue and thus can be more difficult to incorporate into the soil particularly if it is concentrated on individual beds as in A100.

Of the seven intercropping treatments evaluated, the additive treatments ( $\mathrm{L} 100+\mathrm{A} 100$ and $\mathrm{L} 100+\mathrm{A} 30)$ may be the most efficient intercropping approach for producing romaine lettuce hearts where smaller lettuce plants are desired. This additive approach was most efficient because lettuce density was not reduced and alyssum transplants in the additive treatments were able to produce $78 \%$ as many open alyssum inflorescences per transplant as the replacement treatments. However, the competition between alyssum and lettuce grown exclusively for hearts may be slightly greater than occurred in this study because lettuce densities for romaine heart are generally greater than those used in the present study. Romaine lettuce heart production typically occurs on $203.2 \mathrm{~cm}$ wide beds that have five or six rows on the $152 \mathrm{~cm}$ wide bed top. For transplanted lettuce, the additive approach would require that alyssum transplants be planted by hand by the crew of workers that typically follow the transplanter implement to fill in lettuce skips and uncover plants that were planted too deep. At a cost of U.S. $\$ 19.50$ per 1000 alyssum transplants and $\$ 21.50$ per 1000 romaine transplants (which includes the labor cost for transplanting), $\mathrm{L} 100+\mathrm{A} 100$ would have the highest transplanting cost (\$1509) and A100 the lowest (\$1394). More research is needed to determine if the higher transplanting cost of this additive treatment would be offset by the higher potential lettuce yields.

In summary, this study provides the first information on agronomic aspects of strip intercropping transplanted romaine lettuce with alyssum for biological control of aphids in organic systems in replacement arrangements and novel additive arrangements. Alyssum DM was highly correlated with open inflorescences of alyssum, and alyssum flower production increased with alyssum transplant density. Lettuce was more competitive and productive than alyssum in terms of shoot DM at the densities evaluated. Additive intercropping appears to be a more efficient intercropping approach to produce alyssum floral resources for beneficial insects. More research is needed (1) to determine the minimum number of open inflorescences of alyssum per ha necessary to achieve consistent biological control of aphids in lettuce, (2) to understand adult hoverfly movement into and within lettuce fields and if biological control of aphids is influenced by insectary arrangement (i.e. scattered versus concentrated alyssum strips), (3) to compare the effectiveness of insecticides versus biological control of aphids with alyssum intercrops in conventional lettuce, and (4) to determine if there are yield advantages in additive intercropping systems. Furthermore, it would also be useful to know if the agronomic aspects of intercropping alyssum and lettuce differ in transplanted versus direct-seeded production systems. A novel approach for intercropping alyssum and lettuce in direct-seeded fields would involve seeding a desired mixture of pelleted alyssum and pelleted lettuce seed.

\section{Acknowledgments}

I appreciate the assistance of Growers Transplanting Inc. with transplanting services, and to Z-Best Composting Facility and the City of San Jose for donating the compost. I also thank Craig Spielman, Jose Rico, Adriana Marquez, and David Lara for assistance with planting the trials and data collection. I thank Michael Cahn for assistance with irrigation scheduling, and Steve Weinbaum, Jim Leap, and Richard Smith for improving the manuscript.

\section{References}

Al-Doghairi, M.A., Cranshaw, W.S., 1999. Surveys on visitation of flowering landscape plants by common biological control agents in Colorado. J. Kansas Entomol. Soc. 72, 190-196.
Ambrosino, M.D., Luna, J.M., Jepson, P.C., Wratten, S.D., 2006. Relative frequencies of visits to selected insectary plants by predatory hoverflies (Diptera: Syrphidae), other beneficial insects, and herbivores. Environ. Entomol. 35, 394-400.

Begum, M., Gurr, G.M., Wratten, S.D., Hedberg, P.R., Nicol, H.I., 2006. Using selective food plants to maximize biological control of vineyard pests. J. Appl. Ecol. 43, 547-554.

Begum, M., Gurr, G.M., Wratten, S.D., Nicol, H.I., 2004. Flower color affects tritrophic-level biocontrol interactions. Biol. Control 30, 584-590.

Berndt, L.A., Wratten, S.D., 2005. Effects of alyssum flowers on the longevity fecundity, and sex ratio of the leafroller parasitoid Dolichogenidea tasmanica. Biol. Control 32, 65-69.

Brennan, E.B., Boyd, N.S., 2012. Winter cover crop seeding rate and variety effects during eight years of organic vegetables: I. Cover crop biomass production. Agron. J. 104, 684-698.

Breschini, S.J., Hartz, T.K., 2002. Presidedress soil nitrate testing reduces nitrogen fertilizer use and nitrate leaching hazard in lettuce production. HortScience 37 1061-1064.

Bugg, R.L., Colfer, R.G., Chaney, W.E., Smith, H.A., Cannon, J., 2008. Flower flies (Syrphidae) and other biological control agents for aphids in vegetable crops. University of California, Division of Agriculture and Natural Resources.

California Irrigation Management Information System. Department of Water Resources, Office of Water Efficiency. <http://www.cimis.water.ca.gov> (accessed 10.04.13)

Chaney, B., 2003. Insect management for Central Coast lettuce, California Lettuce. Research Board Reports, pp. 165-181.

Chaney, W.E., 1998. Biological control of aphids in lettuce using in-field insectaries. In: Pickett, C.H., Bugg, R.L. (Eds.), Enhancing Biological Control: Habitat Management to Promote Natural Enemies of Arthropod Pests. University of California Press, Berkeley, CA, pp. 73-83.

Colfer, R., 2004. Using habitat management to improve biological control on commercial organci farms in California. In: Proceedings of the California Conference on Biological Control IV, University of California, Berkeley, CA, pp. 55-62.

Cumming, G., 2009. Inference by eye: reading the overlap of independent confidence intervals. Stat. Med. 28, 205-220.

DiTomaso, J.M., Healy, E.A., 2007. Weeds of California and other Western States. University of California, Agriculture and Natural Resources, Oakland.

Fagan, L.L., McLachlan, A., Till, C.M., Walker, M.K., 2010. Synergy between chemical and biological control in the IPM of currant-lettuce aphid (Nasonovia ribisnigri) in Canterbury, New Zealand. Bull. Entomol. Res. 100, 217-223.

Fiedler, A.K., Landis, D.A., Wratten, S.D., 2008. Maximizing ecosystem services from conservation biological control: the role of habitat management. Biol. Control $45,254-271$.

Gaudet, C.L., Keddy, P.A., 1988. A comparative approach to predicting competitive ability from plant traits. Nature 334, 242-243.

Gillespie, M., Wratten, S., Sedcole, R., Colfer, R., 2011. Manipulating floral resources dispersion for hoverflies (Diptera: Syrphidae) in a California lettuce agroecosystem. Biol. Control 59, 215-220.

Goulson, D., Wright, N.P., 1998. Flower constancy in the hoverflies Episyrphus balteatus (Degeer) and Syrphus ribesii (L.) (Syrphidae). Behav. Ecol. 9, 213-219.

Hogg, B.N., Bugg, R.L., Daane, K.M., 2011a. Attractiveness of common insectary and harvestable floral resources to beneficial insects. Biol. Control 56, 76-84.

Hogg, B.N., Nelson, E.H., Mills, N.J., Daane, K.M., 2011b. Floral resources enhance aphid suppression by a hoverfly. Entomol. Exp. Appl. 141, 138-144.

Hopper, J.V., Nelson, E.H., Daane, K.M., Mills, N.J., 2011. Growth, development and consumption by four syrphid species associated with the lettuce aphid, Nasonovia ribisnigri, in California. Biol. Control 58, 271-276.

Johanowicz, D.L., Mitchell, E.R., 2000. Effects of sweet alyssum flowers on the longevity of the parasitoid wasps Cotesia marginiventris (Hymenoptera: Braconidae) and Diadegma insulare (Hymenoptera: Ichneumonidae). Fla. Entomol. 83, 41-47.

Jonsson, M., Wratten, S.D., Landis, D.A., Gurr, G.M., 2008. Recent advances in conservation biological control of arthropods by arthropods. Biol. Control 45, $172-175$.

Karrou, M., 1998. Observations on effect of seeding pattern on water-use efficiency of durum wheat in semi-arid areas of Morocco. Field Crops Res. 59, 175-179.

Keddy, P., Nielsen, K., Weiher, E., Lawson, R., 2002. Relative competitive performance of 63 species of terrestrial herbaceous plants. J. Veg. Sci. 13, 5-16.

Landis, D.A., Wratten, S.D., Gurr, G.M., 2000. Habitat management to conserve natural enemies of arthropod pests in agriculture. Annu. Rev. Entomol. 45, 175201.

Liu, Y.B., 2004. Distribution and population development of Nasonovia ribisnigri (Homoptera: Aphididae) in iceberg lettuce. J. Econ. Entomol. 97, 883-890.

McCreight, J.D., Liu, Y.B., 2012. Resistance to lettuce aphid (Nasonovia ribisnigri) Biotype 0 in wild lettuce accessions PI 491093 and PI 274378. HortScience 47, $179-184$.

Monterey County Agricultural Commissioner, 2011. Monterey County Crop Report 2010. Agricultural Commissioner, Monterey Country, California, p. 24.

Nafziger Jr., T.D., Fadamiro, H.Y., 2011. Suitability of some farmscaping plants as nectar sources for the parasitoid wasp, Microplitis croceipes (Hymenoptera: Braconidae): effects on longevity and body nutrients. Biol. Control 56, 225-229.

Palumbo, J.C., Castle, S.J., 2009. IPM for fresh-market lettuce production in the desert southwest: the produce paradox. Pest Manag. Sci. 65, 1311-1320.

Parolin, P., Bresch, C., Desneux, N., Brun, R., Bout, A., Boll, R., Poncet, C., 2012. Secondary plants used in biological control: a review. Int. J. Pest Manag. 58, $91-$ 100. 
Pico, F.X., Retana, J., 2003. Seed ecology of a Mediterranean perennial herb with an exceptionally extended flowering and fruiting season. Bot. J. Linn. Soc. 142 273-280.

Pumarino, L., Alomar, O., 2012. The role of omnivory in the conservation of predators: Orius majusculus (Heteroptera: Anthocoridae) on sweet alyssum. Biol. Control 62, 24-28.

Schneider, F., 1948. Beitrag zur Kenntnis der Generationsverhaltnisse und Diapause rauberischer Schwebfliegen (Syrphidae: Diptera). Mitt. Schweiz. Entomol. Ges. 21, 245-285.

Sivinski, J., Aluja, M., Holler, T., 2006. Food sources for adult Diachasmimorpha longicaudata, a parasitoid of tephritid fruit flies: effects on longevity and fecundity. Entomol. Exp. Appl. 118, 193-202.

Smith, H.A., Chaney, W.E., 2007. A survey of syrphid predators of Nasonovia ribisnigri in organic lettuce on the Central Coast of California. J. Econ. Entomol. 100, 3948
Smith, H.A., Chaney, W.E., Bensen, T.A., 2008. Role of syrphid larvae and other predators in suppressing aphid infestations in organic lettuce on California's Central Coast. J. Econ. Entomol. 101, 1526-1532.

Vattala, H.D., Wratten, S.D., Phillips, C.B., Wackers, F.L., 2006. The influence of flower morphology and nectar quality on the longevity of a parasitoid biological control agent. Biol. Control 39, 179-185.

Westfall, P.H., Tobias, R.D., Rom, D., Wolfinger, R.D., Hochberg, Y., 1999. Multiple Comparisons and Multiple Tests using SAS. SAS Institute, Cary, NC.

Willey, R.W., 1979. Intercropping - its importance and reserach needs. Part 1. Competition and yield advantage. Field Crop Abstracts 32, 1-10.

Wisler, G.C., Duffus, J.E., 2000. A century of plant virus management in the Salinas valley of California, 'East of Eden'. Virus Res. 71, 161-169. 